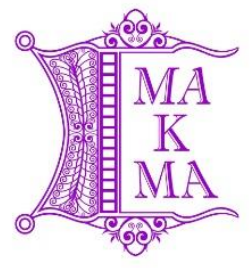

Majalah Kesehatan Masyarakat Aceh (MaKMA) http://ojs.serambimekkah.ac.id/index.php/makma

\title{
ANALISIS FAKTOR-FAKTOR YANG MEMPENGARUHI KEPUASAN PASIEN DI RUMAH SAKIT UMUM CITRA HUSADA SIGLI
}

\author{
T. Alamsyah ${ }^{\bowtie}$ \\ Politeknik Kesehatan Aceh, Jurusan Keperawatan Banda Aceh, Indonesia
}

${ }^{凶}$ Alamat Korespondensi: Politeknik Kesehatan Aceh, Jurusan keperawatan Banda Aceh, Email: aalams@ hotmail.com

\begin{abstract}
ABSTRAK
Pada dasarnya, kepuasan tidak dapat dipisahkan dari upaya memberikan layanan tenaga medis dan nonmedis dalam memenuhi kebutuhan dan keinginan pasien. Salah satu pendekatan terhadap kualitas layanan yang banyak digunakan adalah model SERQUAL yang dikembangkan oleh Parasuramanthat termasuk tangible, reliability, responsiveness, assurance dan emphaty. Penelitian ini menggunakan metode eksplanatif dengan melihat tangible, reliability, responsiveness, assurance dan empathy terhadap kepuasan pasien yang berobat di Rumah Sakit Citra Husada Sigli. Sampel penelitian sebanyak 60 responden. Teknik pengumpulan data dilakukan dengan observasi dan pembagian kuesioner. Dari Analisis Univariat didapat nilai pada hasil variabel dependen / kepuasan pasien yaitu sebanyak 50 responden puas $(83,3 \%)$, sedangkan hasil variabel independen yang mendapat skor tertinggi pada penjaminan ada 59 responden yang dikategorikan baik $(98,3 \%)$ dan 1 responden yang dikategorikan kurang baik $(1,7 \%)$, terdapat 58 responden yang dikategorikan responsif $(96,7 \%)$ dan 2 responden yang dikategorikan kurang responsif $(3,3 \%)$. Pada variabel reliabilitas, terdapat 55 responden yang dikategorikan andal $(91,7 \%)$ dan 5 responden dikategorikan kurang reliabel $(8,3 \%)$. Selanjutnya variabel empati diketahui sebanyak 54 responden yang dikategorikan baik $(90,0 \%)$ dan 6 responden yang dikategorikan kurang baik (10,0\%). Dan tangible diketahui 52 responden yang dikategorikan baik $(86,7 \%)$ dan 8 responden yang dikategorikan kurang baik (13,3\%). Dari hasil analisis bivariat didapatkan hasil bahwa, pengaruh tertinggi adalah bentuk fisik dengan nilai $0,628<3,84$, diikuti oleh empati dengan nilai $0,83<3,84$. Selanjutnya pada daya tanggap dengan nilai $0,36<3,84$, kemudian pada jaminan dengan nilai $0,017<3,84$ dan terendah pada keandalan dengan nilai 0,007 $<3,84$. Bentuk kepuasan pasien pada layanan persalinan Rumah Sakit telah hampir sama diterima oleh pasien yang berobat di Rumah Sakit Citra Husada Sigli.
\end{abstract}

Kata Kunci: Kepuasan Pasien. 


\title{
ANALYSIS FACTORS THAT AFFECT PATIENT SATISFACTION IN CITRA HUSADA SIGLI HOSPITAL
}

\begin{abstract}
In essence, satisfaction cannot be separated from efforts to provide medical and nonmedical labor services in meeting the needs and desires of the patients. One approach to service quality that many used as a SERQUAL Model developed by Parasuramanthat includes tangible, reliability, responsiveness, Assurance and Emphaty. From the type of research used is explanatory research methods about Tangible, reliability, responsiveness, Assurance and Empathyon patient satisfaction that treatment at Citra Husada Sigli Hospital. Samples taken 60 respondents. Technique of collecting data is done by observation and division of questionnaires. From Univariate Analysis got value on result of variable dependent / satisfaction of patient that is as much 50 responder satisfied with percentage as much $83.3 \%$. While the result of independent variables that get the highest score is on the assurance there are 59 respondents who categorized good with the percentage of $98.3 \%$ and 1 respondent who categorized less well with a percentage of $1.7 \%$. Followed the responsiveness there are 58 respondents who categorized responsiveness with the percentage of $96.7 \%$ and 2 respondents who categorized less responsive with a percentage of $3.3 \%$. On the reliability that there are 55 respondents who categorized reliably with the percentage of $91.7 \%$ and 5 respondents categorized less reliable with a percentage of $8.3 \%$. Next on empathy there are 54 respondents who categorized both with percentage as much as $90.0 \%$ and 6 respondents who categorized less good with percentage of $10.0 \%$. And the last tangible form there are 52 respondents who categorized both the percentage of $86.7 \%$ and 8 respondents who categorized less good with a percentage of $13.3 \%$. From result of bivariate analysis got result of highest influence is in physical form with value $0,628<3.84$, followed by empathy with value $0,83<3.84$. Next on the responsiveness with a value of $0.36<3.84$, then on the guarantee with a value of $0.017<3.84$ and the lowest on reliability with a value of $0.007<3.84$. The form of patient satisfaction on the hospital's labor service has been almost equally accepted by patient who medicated at Citra Husada Sigli Hospital.
\end{abstract}

Keywords: Patient Satisfaction 


\section{PENDAHULUAN}

Pada saat ini masalah kesehatan sudah menjadi kebutuhan yang utama bagi masyarakat. Kebutuhan yang dimaksud adalah kebutuhan untuk mendapatkan pelayanan kesehatan yang prima. Seiring dengan meningkatnya taraf kehidupan masyarakat, maka semakin meningkat pula tuntutan masyarakat akan nilai-nilai kesehatan. Dalam upaya mencapai efisiensi penyelenggara rumah sakit, upaya pendayagunaan fasilitas secara lebih baik kini menjadi salah satu kegiatan pokok.

Sesuai dengan UU Kesehatan No. 36 tahun 2009, yang menyatakan bahwa; (a) Kesehatan merupakan hak asasi manusia dan salah satu unsur kesejahteraan yang harus diwujudkan sesuai dengan cita-cita bangsa Indonesia sebagaimana dimaksud dalam Pancasila dan UUD Negara Republik Indonesia tahun 1945. (b) Setiap kegiatan dalam upaya untuk memelihara dan meningkatkan derajat kesehatan masyarakat yang setinggitingginya dilaksanakan berdasarkan prinsip-prinsip non diskriminatif, partisipatif, dan berkelanjutan dalam ranga pembentukkan sumber daya manusia Indonesia, serta peningkatan ketahanan dan daya saing bangsa bagi pembangunan nasional (c) Setiap hal yang menyebabkan terjadinya gangguan kesehatan pada masyarakat Indonesia akan menimbulkan kerugian ekonomi yang besar bagi Negara, dan setiap upaya peningkatan derajat kesehatan masyarakat juga berarti investasi bagi pembangunan Negara.

Rumah Sakit adalah suatu organisasi yang melakukan tenaga medis professional yang terorganisir serta sarana kedokteran yang permanen menyelenggarakan

pelayanan

kedokteran, asuhan keperawatan,yang berkesinambungan, diagnosis serta pengobatan penyakit yang diderita oleh pasien. ${ }^{[1]}$

Hakikat dasar dari rumah sakit adalah pemenuhan kebutuhan dan tuntutan pasien yang mengharapkan penyelesaian masalah kesehatannya pada rumah sakit.Pasien mengharapkkan pelayanan yang siap, cepat, tanggap dan nyaman terhadap keluhan penyakit pasien. Dalam memenuhi kebutuhan pasien tersebut, pelayanan prima menjadi utama dalam pelayanan yaitu dengan mempunyai keterampilan khusus, diantaranya memahami produk secara mendalam, berpenampilan menarik, bersikap ramah dan bersahabat, renponsif (peka) dengan pasien, menguasai pekerjaan, berkomunikasi secara efektif dan mampu menanggapi keluhan pasien secara professional. ${ }^{[2]}$

Kepuasan pasien merupakan hal yang sangat subyektif, sulit diukur, dapat berubah-ubah, serta terdapat banyak sekali faktor yang berpengaruh sebanyak dimensi di dalam kehidupan manusia. Subyektivitas tersebut bisa berkurang dan bahkan bisa menjadi obyektif bila cukup banyak pendapat yang sama terhadap sesuatu hal. Oleh karena itu, untuk mengkaji kepuasan pasien dipergunakan suatu instrumen penelitian yang cukup valid disertai dengan metode penelitian yang baik. ${ }^{[1]}$

Rumah Sakit Umum Citra Husada Sigli merupakan Rumah Sakit swasta yang memberikan pelayanan kesehatan kepada masyarakat yang berdomisil di Kota Sigli. Secara fungsional Rumah Sakit Umum Citra Husada Sigli semakin baik kearah pelayanan kesehatan yang menyeluruh dan terintegrasi seiring dengan berkembangnya ilmu dan teknologi. Baik dalam upaya penyembuhan bagi pasien yang sakit ataupun bagi pasien 
yang membutuhkan konsultasi kesehatan dan upaya pencegahan serta peningkatan kesehatan.

Rumah Sakit Umum Citra Husada Sigli dituntut untuk meningkatkan kualitas akan pelayanan jasa kesehatan yang lebih baik, tidak saja pelayanan kesehatan yang bersifat menyembuhkan saja, tetapi lembaga kesehatan juga dituntut untuk dapat memberikan kepuasan pasien rumah sakit.

Rumah Sakit Umum Citra Husada Sigli berusaha memberikan nilai yang lebih bagi pasiennya. Sedangkan pelayanan yang baik juga merupakan suatu keharusan apabila manajemen rumah sakit ingin menarik jumlah pasien yang lebih banyak lagi. Sejalan dengan persaingan yang semakin tajam saat ini, banyak berbagai fasilitas yang ditawarkan atau yang ada pada rumah sakit kepada pasien. Manajemen harus bisa menerapkan dan menetapkan kebijakan serta strategi yang tepat untuk pasien yang berobat di rumah sakit tersebut.

Rumah Sakit Umum Citra Husada Sigli juga menawarkan fasilitas-fasilitas baru semakin banyak ragamnya dan bervariasi. Salah satunya dengan beberapa kemudahan yang dapat disesuaikan bagi para pasien yang ingin berobat. Salah satunya dengan memberikan fasilitas fisik, meliputi gedung, tempat parkir yang luas, kebersihan yang terjaga dan fasilitas pelayanan administrasi yang tertata rapi yang tentunya akan memberikan kemudahan bagi para pasien, hal ini yang menjadikan Rumah Sakit Umum Citra Husada Sigli berbeda dan memiliki nilai lebih dibandingkan dengan Rumah Sakit lain.

\section{HASIL}

Berdasarkan hasil penelitian yang dilakukan dengan menggunakan chi square test terhadap terhadap kepuasan pasien yang berobat ke Rumah Sakit Umum Citra Husada Sigli sebagai berikut:
Berdasarkan pengumpulan data awal, jumlah pasien yang diperoleh dari Rumah Sakit Umum Citra Husada Sigli dari tahun 2014 sampai tahun 2016 menunjukkan adanya kenaikan. Pada Tahun 2014 jumlah pasien yang berobat di Rumah Sakit Umum Citra Husada Sigli sebanyak 28.027 pasien, pada tahun 2015 jumlah pasien yang berobat sebanyak 30.016 pasien, dan pada tahun 2016 terjadi peningkatan jumlah pasien yaitu sebanyak 30.912 pasien. Dari uraian tersebut dapat diketahui jumlah pasien yang berobat di Rumah Sakit Umum Citra Husada Sigli dari tahun ke tahun mengalami peningkatan yang sangat signifikan, yaitu sekitar 1.200 pasien pada tahun 2015, sedangkan pada tahun terakhir, yaitu pada tahun 2016 jumlah pasien mengalami kenaikan sekitar 900 pasien.

Tujuan Penelitian ini dilakukan untuk mengetahui Analisis faktor-faktor yang mempengaruhi kepuasan pasien terhadap pelayanan petugas di Rumah Sakit Umum Citra Husada Sigli tahun 2017

\section{METODE}

Dalam penelitian ini, metode yang digunakan dengan eksplanatory yaitu penelitian yang bermaksud menjelaskan kedudukan variabel-variabel yang diteliti serta hubungan antara satu variabel dengan variabel yang lain.

Populasi penelitian ini adalah seluruh pasien yang berobat di Rumah Sakit Umum Citra Husada Sigli yang berjumlah sebanyak 60 orang.

Pengaruh bentuk fisik diketahui bahwa dari 25 responden yang menyatakan wujud fisik (Tangible) petugas baik sebanyak 18 responden (72\%). Sedangkan dari 35 responden yang menyatakan wujud fisik yang diberikan petugas tidak baik sebanyak 22 responden $(62,9 \%)$. 
Berdasarkan uji statistik, didapatkan pvalue 0,016 yang berarti $p$-value $<0,05$ sehingga (Ha) diterima yang berarti ada pengaruh wujud fisik (Tangible) petugas rumah sakit terhadap kepuasan pasien [Tabel. 1].

Pengaruh Kehandalan (Reliability) Dengan Kepuasan Pasien diketahui bahwa dari 32 responden yang menyatakan kehandalan (Reliability) petugas baik sebanyak 23 responden (71,9\%). Sedangkan dari 28 responden yang menyatakan kehandalan (Reliability) yang diberikan petugas tidak baik sebanyak 20 responden $(71,4 \%)$. Berdasarkan uji statistik, didapatkan p-value0,002 yang berarti p-value $<0,05$ sehingga ( $\mathrm{Ha}$ ) diterima yang berarti ada pengaruh kehandalan (Reliability) petugas rumah sakit terhadap kepuasan pasien [Tabel. 2].

Dari 35 responden yang menyatakan daya tanggap ( Responsiveness ) petugasnya tanggap sebanyak 23 responden $(65,7 \%)$. Sedangkan dari 25 responden yang menyatakan daya tanggap (Responsiveness)yang diberikan petugas tidaktanggap sebanyak 20 responden $(71,4 \%)$. Berdasarkan uji statistik, didapatkan $p$-value 0,021 yang berarti $p$ value $<0,05$ sehingga (Ha) diterima yang

\section{PEMBAHASAN}

Melihat hasil rekapitulasi kepuasan pasien yang berobat di Rumah Sakit Umum Citra Husada Sigli, secara keseluruhan pasiensudah hamper sepenuhnyamerasa puas dengan pelayanan yang diberikan petugas rumah sakit baik dari faktor wujud fisik, keandalan, daya tanggap, jaminan maupun empati. Hal ini dapat dilihat dari hasil analisis perbandingan pengaruh variabel bebas terhadap variabel terikat dengan menggunakan chi-square test. berarti ada pengaruh daya tanggap (Responsiveness) petugas rumah sakit terhadap pengaruh pasien [Tabel. 3].

Berdasarkan variabel jaminasn kesehatan, diketahui bahwa dari 28 responden yang menyatakan Jaminan (Assurance) petugas baik sebanyak 19 responden $(67,9 \%)$. Sedangkan dari 32 responden yang menyatakan Jaminan (Assurance) yang diberikan petugas tidak baik sebanyak 20 responden $(62,5 \%)$. Hasil uji statistik, menunjukkan p-value 0,037 yang berarti $\mathrm{p}$-value $<0,05$ sehingga $(\mathrm{Ha})$ diterima yang berarti ada pengaruh Jaminan (Assurance) petugas rumah sakit terhadap pengaruh pasien [Tabel. 4].

Berdasarkan [Tabel. 5], diketahui bahwa dari 30 responden yang menyatakan Empati (Empathy) petugas baik sebanyak 21 responden (70\%). Sedangkan dari 30 responden yang menyatakan Empati (Empathy)yang diberikan petugas tidak baik sebanyak 20 responden (66,7\%). Berdasarkan uji statistik, didapatkan pvalue0,010 yang berarti $p$-value $<0,05$ sehingga (Ha) diterima yang berarti ada pengaruh Empati (Empathy) petugas rumah sakit terhadap pengaruh pasien di Rumah Sakit Umum Citra Husada Sigli.

\section{Pengaruh wujud fisik (Tangible) petugas rumah sakit terhadap kepuasan pasien.}

Penelitian ini sejalan dengan penelitian Roslina (2008) yang menyatakan berkualitas dan puas sebanyak $69,60 \%$ dan yang menyatakan tidak berkualitas dan tidak puas sebanyak 57,90\%. Dan dari hasil uji beda proporsi dengan Chi-Square diperoleh pada level of significan $\alpha=0,05$ dengan $\mathrm{Df}=1$ diketahui Probability $(\mathrm{P})=0,007<\alpha(0,05)$ hasil uji statistik menunjukan bahwa $\mathrm{Ha}$ diterima yang berarti ada hubungan secara signifikan antara tangibles dengan kepuasan pasien rawat jalan pada Puskesmas di 
Kecamatan Kuta Blang Kabupaten Bireuen Tahun 2008.

Sesuatu yang nampak atau nyata seperti ; penampilan para pegawai, dan fasilitasfasilitas fisik, lainnya seperti peralatan dan perlengkapan yang menunjang pelaksanaan pelayanan rumah sakit. Wujud fisik (tangible) adalah dimensi yang berkenaan dengan daya tarik fasilitas fisik, perlengkapan, dan material yang digunakan perusahaan, serta penampilan karyawan.

Kotler mendefinisikan wujud fisik (tangible) sebagai kemampuan suatu perusahaan dalam menunjukkan eksistensinya kepada pihak luar. Penampilan dan kemampuan sarana serta prasarana fisik perusahaan dan keadaan lingkungan sekitarnya adalah bukti nyata dari pelayanan yang diberikan oleh pemberi jasa. Fasilitas fisik tersebut meliputi gedung, perlengkapan dan peralatan yang dipergunakan (teknologi), serta penampilan pegawainya. ${ }^{[1]}$

Sarana dan prasarana yang tersedia di Rumah Sakit juga sangat mempengaruhi tingkat kepuasan pasien mendapat pelayanan. Peralatan medis yang lengkap membuat pasien merasa nyaman dan terkontrol penyakitnya sehingga pasien akan merasa puas dan cenderung mendorong pasien untuk segera sembuh. Demikian juga dengan kebersihan ruangan, ruangan yang bersih dan rapi membuat pasien merasa nyaman dan tidak terjangkit virus penyakit lain. ${ }^{[3]}$

Pelayanan yang diberikan dapat dirasakan langsung oleh pasien dan keluarganya sehingga mereka lebih aman dalam pengobatan. Dapat dirasa merupakan pelaksanaan kegiatan atau pelayanan yang diberikan oleh petugas dalam bentuk nyata dan jelas. Dalam memberikan pelayanan kesehatan setiap upaya yang diselenggarakan secara sendiri atau bersama-sama dalam Puskesmas untuk memelihara kesehatan perorangan, keluarga, kelompok atau masyarakat. ${ }^{[4]}$

\section{Pengaruh kehandalan (Reliability) petugas rumah sakit terhadap kepuasan pasien.}

Penelitian ini sejalan dengan penelitian Roslina (2008) yang menyatakan handal dan puas sebanyak $73,30 \%$ dan yang menyatakan tidak handal dan tidak puas sebanyak 55,10\%. Dan dari hasil uji beda proporsi dengan Chi-Square diperoleh pada level of significan $\alpha=0,05$ dengan $\mathrm{Df}=1$ diketahui Probability $(\mathrm{P})=0,005<\alpha(0,05)$ hasil uji statistik menunjukan bahwa $\mathrm{Ha}$ diterima yang berarti ada hubungan secara signifikan antara kehandalan dengan kepuasan pasien rawat jalan pada Puskesmas di Kecamatan Kuta Blang Kabupaten Bireuen Tahun 2008.

Keandalan (reliability) yaitu kemampuan perusahaan untuk memberikan pelayanan sesuai dengan apa yang dijanjikan secara akurat dan terpercaya. Kinerja harus sesuai dengan harapan pasien yang berarti ketepatan waktu, pelayanan yang sama untuk semua pelanggan tanpa kesalahan, sikap yang simpatik, dan dengan akurasi yang tinggi. Pemenuhan janji dalam pelayanan akan mencerminkan kredibilitas berusahaan. ${ }^{[2]}$

Pelayanan yang baik dan memuaskan membutuhkan kehandalan dan kemampuan paramadis dalam memberikan jasa pelayanan. Kemampuan seorang paramedis dalam memberikan pelayanan dipengaruhi dari dalam diri sendiri dan dari luar seperti pendidikan dan pengetahuan lainnya. ${ }^{[4]}$

Kehandalan paramedis dalam memberi pelayanan tidak saja berasal dari diri pribadi tapi juga dipengaruhi oleh dorongan dari luar. Dorongan dari luar ini adalah adanya kerjasama dan saling membantu serta saling mendukung dalam melaksanakan pekerjaannya masing-masing. ${ }^{[5]}$

Pandangan baru menyimpulan, pelayanan kesehatan dan dunia perumahsakitan dewasa ini, dan juga dalam menyongsong era globalisasi, maka peran 
dokter di rumah sakit dan hubungannya dengan pihak lain di Rumah Sakit perlu ditata ulang. Seharusnya memang ada semacam hubungan simbiose mutualistis (saling menguntungkan) dalam hubungan dokter dengan pasien, dengan memperhatikan mutu pelayanan dan kepentingan pasien yang dilayani. ${ }^{[6]}$

\section{Pengaruh Daya Tanggap (Responsiveness) Petugas Rumah Sakit Terhadap Pengaruh Pasien.}

Penelitian ini sejalan dengan penelitian Roslina (2008)yang menyatakan tanggap dan puas sebanyak $70,60 \%$ dan yang menyatakan tidak tanggap dan tidak puas sebanyak 55,80\%. Dan dari hasil uji beda proporsi dengan Chi-Square diperoleh pada level of significan $\alpha=0,05$ dengan $\mathrm{Df}=1$ diketahui Probability $(\mathrm{P})=0,009<\alpha \quad(0,05)$ hasil uji statistik menunjukan bahwa $\mathrm{Ha}$ diterima yang berarti ada hubungan secara signifikan antara ketanggapan dengan kepuasan pasien rawat jalan pada Puskesmas di Kecamatan Kuta Blang Kabupaten Bireuen Tahun 2008.

Daya tanggap (responsiveness) yaitu suatu kebijakan untuk membantu dan memberikan pelayanan yang cepat (responsif) dan tepat kepada pelanggan, dengan penyampaian informasi yang jelas. Membiarkan konsumen menunggu merupakan persepsi yang negatif dalam kualitas pelayanan. ${ }^{[3]}$

Kepuasan terhadap dimensi daya tanggap adalah berdasarkan persepsi. Karena persepsi mengandung aspek psikologis, maka faktor komunikasi, emosi dan situasi fisik disekeliling konsumen yang menerima merupakan hal yang mempengaruhi penilaian konsumen terhadap pelayanan yang diberikan. Mengkomunikasikan mengenai proses pelayanan yang diberikan akan membentuk persepsi yang lebih positif kepada para konsumen. ${ }^{[4]}$
Ketanggapan paramedis terhadap permasalahan yang dialami pasien sangat mempengaruhi tingkat kepuasan pasien dalam berobat. Paramedis dalam menanggapi masalah pasien tidak boleh mengacuhkan dan cepat bosan karena hal tersebut dapat membuat pasien tidak puas dan merasa tidak dipedulikan saat perawatannya. Ketanggapan paramedis dalam menangani permasalahan yang timbul pada pasien merupakan suatu hal yang harus terus dilatih mengingat fungsi paramedis yaitu untuk bertindak tanggap dan cepat dalam menangani keluhan-keluhan penyakit pasien. Pasien yang datang ke Rumah Sakit karena penyakitnya membutuhkan penanganan segera dari paramedis yang tentunya membutuhkan ketanggapan yang serius dari paramedis. ${ }^{[6]}$

Hal yang sama juga pemahaman terhadap budaya melayani dirasakan masih kurang. Hal tersebut terlihat dalam melakukan tugasnya perawat kadangkadang kurang tanggap dan kurang ramah. Selain itu uraian tugas, peran dan fungsi setiap katagori perawat berdasarkan jenjang pendidikan belum menetapkan secara jelas dan kualifkasi tenaga perawat untuk jenjang jenis keperawatan tertentu masih perlu ditetapkan. Kesemuanya itu akan mempengaruhi suatu mutu pelayanan khususnya asuhan keperawatan di rumah sakit. Keadaan tersebut sering terjadi keluhan khalayak ramai. ${ }^{[4]}$

\section{Pengaruh Jaminan (Assurance) Petugas Rumah Sakit Terhadap Pengaruh Pasien}

Penelitian terkait yang menyatakan yakin dan puas sebanyak $73,20 \%$ dan yang menyatakan tidak yakin dan tidak puas sebanyak $63,20 \%$. Dan dari hasil uji beda proporsi dengan Chi-Square diperoleh pada level of significan $\alpha=0,05$ dengan $\mathrm{Df}=1$ diketahui Probability $(\mathrm{P})=0,001<\alpha(0,05)$ hasil uji statistik menunjukan bahwa $\mathrm{Ha}$ diterima yang berarti ada hubungan secara signifikan antara keyakinan dengan 
kepuasan pasien rawat jalan pada Puskesmas di Kecamatan Kuta Blang Kabupaten Bireuen Tahun 2008.

Jaminan (assurance) atau kepastian adalah pengetahuan, kesopansantunan, dan kemampuan para pegawai perusahaan untuk menumbuhkan rasa percaya para nasabah kepada perusahaan". Terdiri dari beberapa komponen antara lain komunikasi (communication). Kredibilitas (credibility), keamanan (security), kompetensi (competence). Dan sopan santun (courtesy). ${ }^{[5]}$

Kemampuan paramedis dalam memberikan keyakinan pada pasien bahwa penyakitnya akan segera sembuh merupakan hal yang sangat penting dilakukan. Mengingat pasien di samping diobati dengan obat-obatan juga perlu dilakukan pengobatan ke dalam rohani pasien. Pengobatan rohani ini salah satunya berupa pemberian keyakinan bahwa penyakit atau rasa sakitnya akan segera sembuh. Hal ini membuat pasien mendapat dorongan untuk kesembuhan dirinya. Memberikan keyakinan kepada pasien tentang kesembuhannya merupakan salah satu faktor pendukung yang dapat membuat pasien cepat merasa sembuh yang juga merupakan suatu proses untuk mencapai kesembuhan yang sesungguhnya. Kemampuan paramedis dalam memberikan keyakinan kepada pasien sangat dituntut dan harus selalu dikembangkan oleh setiap paramedis.

\section{Pengaruh Empati (Empathy) Petugas Rumah Sakit Terhadap Pengaruh Pasien.}

Penelitian terkait menyatakan mampu dan puas sebanyak $77,40 \%$ dan yang

\section{KESIMPULAN DAN SARAN}

Berdasarkan hasil penelitian, diperoleh hasil sebagai berikut:

Ada pengaruh wujud fisik (Tangible) petugas rumah sakit terhadap kepuasan pasien di Rumah Sakit Umum menyatakan tidak mampu dan tidak puas sebanyak 65,90\%. Dan dari hasil uji beda proporsi dengan Chi-Square diperoleh pada level of significan $\alpha=0,05$ dengan $\mathrm{Df}=1$ diketahui Probability $(\mathrm{P})=0,000<\alpha(0,05)$ hasil uji statistik menunjukan bahwa $\mathrm{Ha}$ diterima yang berarti ada hubungan secara signifikan antara empati dengan kepuasan pasien rawat jalan pada Puskesmas di Kecamatan Kuta Blang Kabupaten Bireuen Tahun 2008.

Memberikan perhatian individu pasien secara khusus, dimensi Empaty memiliki ciri-ciri: kemauan untuk melakukan pendekatan, memberikan perlindungan dan usaha untuk mengerti keinginan pasien, tahu kebutuhan dan perasaan pasien. Empati adalah "memberikan perhatian yang tulus dan bersifat individual atau pribadi, yang diberikan kepada pasien dengan, berupaya memahami keinginan konsumen. Dimana suatu perusahaan diharapkan memiliki pengertian dan pengetahuan tentang nasabah, memahami kebutuhan nasabah secara spesifik, serta memiliki waktu pengoperasian yang nyaman bagi nasabah.

Pasien dalam kesehariannya menunggu penyakitnya sembuh selalu membutuhkan empati paramedis. Perilaku seseorang atau perasaan yang ikut merasakan akan yang dirasakan oleh orang lain. Perasaan empati dalam pelayanan yang diberikan oleh petugas kesehatan atau dokter seakan-akan bukan karena terpaksa melainkan tugas yang harus dilaksanakan sebagai pemberi pelayanan. Petugas harus merasa empati terhadap pasien, sehingga pasien merasa puas.

Citra Husada Sigli. Berdasarkan uji statistik, didapatkan p-value0,016 yang berarti $p$ value $<0,05$.

\begin{tabular}{rrr} 
Ada & pengaruh & \multicolumn{2}{c}{ kehandalan } \\
(Reliability) & petugas & rumah sakit
\end{tabular}


terhadap kepuasan pasien di Rumah Sakit Umum Citra Husada Sigli. Berdasarkan uji statistik, didapatkan p-value 0,002 yang berarti $\mathrm{p}$-value $<0,05$.

Ada pengaruh daya tanggap (Responsiveness) petugas rumah sakit terhadap pengaruh pasien di Rumah Sakit Umum Citra Husada Sigli. Berdasarkan uji statistik, didapatkan p-value 0,021 yang berarti $\mathrm{p}$-value $<0,05$.

Ada pengaruh Jaminan (Assurance) petugas Rumah Sakit terhadap pengaruh pasien di Rumah Sakit Umum Citra Husada Sigli. Berdasarkan uji statistik, didapatkan p-value 0,037 yang berarti p-value $<0,05$.

Ada pengaruh Empati (Empathy) petugas Rumah Sakit terhadap pengaruh pasien di Rumah Sakit Umum Citra Husada Sigli. Berdasarkan uji statistik, didapatkan p-value 0,010 yang berarti $p$-value $<0,05$.

Berdasarkan kesimpulan yang telah dijelaskan sebelumnya di atas maka saran yang dapat diberikan adalah sebagai berikut:

\section{DAFTAR PUSTAKA}

1. Cesarino, 2015, Pengaruh Pelayanan, Harga dan Fasilitas Terhadap Kepuasan Pasien, Studi Kasus Pada Rumah Sakit Darno Surabaya, Skripsi Fakultas Ilmu Sosial dan Ilmu Politik, Universitas Pembangunan Nasional.

2. Fidela, 2012, Evaluasi Kualitas Pelanayan Terhadap Kepuasan Pasien Rawat Jalan Perserta BPJS di RSUD Panembahan, Senopati Bantul. Skripsi, Program Studi Manajemen Rumah Sakit Universitas Muhammadiya Yogyakarta.

3. Budi, 2015, Kualitas Pelayanan Rumah Sakit Umum Daerah (Studi Tentang Kepuasan Pasien Rawat Inap, Peserta Jamkesmas Pada Rumah Umum Daerah, Kabupaten Indramayu) Jurnal Aspirasi, Vol 5 No 2.
Dalam rangka pemenuhan kebutuhan dan kepuasan pasien atas pelayanan yang berkualitas maka diperlukan empati, ketanggapan dan keandalan petugas rumah sakit yang memenuhi syarat yang dapat diwujudkan melalui pemberian pelatihan dan peningkatan jenjang pendidikan yang dimilki petugas rumah sakit

Selain itu, upaya penambahan fasilitas dan sarana pelayanan kesehatan juga perlu mendapat perhatian dengan lebih terutama jenis sarana pelayanan yang sangat dibutuhkan oleh pasien dalam rangka pemenuhan kebutuhan pelayanan kesehatan yang lebih berkualitas dan memuaskan.

Kehandalan dalam memberikan pelayanan sangat diperlukan bagi setiap paramedis. Oleh karena itu diharapkan kepada paramedis untuk memberikan jasa pelayanan yang lebih cepat, tepat dan baik bagi pasien guna memberikan pelayanan yang memuaskan bagi pasien.

4. Ari, 2009. Pengaruh Tarif, Fasilitas Dan Pelayanan Terhadap Tingkat Kepuasan Konsumen Rawat Inap, Di Rumah Sakit PKU Muhammadiyah Karang Anyar. Skripsi Fakultas Keguruan Dan Ilmu Pendidikan Universitas Muhammadiyah Surakarta

5. Ignatius, 2012, Implikasi Pelayanan Prima (Service Excelent Dan Paket Agenda Reformasi Layanan Kesehatan) Jurnal Reformasi Vol 2 No 2 Juli.

6. Ira, 2013. Analisis Kualitas Pelayanan Rumah Sakit Terhadap Pasien Menggunakan Ppendekan Lean Servperf. Spectrum Industri 2013, Vol 11 No 2 


\section{LAMPIRAN}

Tabel [1]. Distribusi Pengaruh Wujud Fisik Dengan Kepuasan Pasien

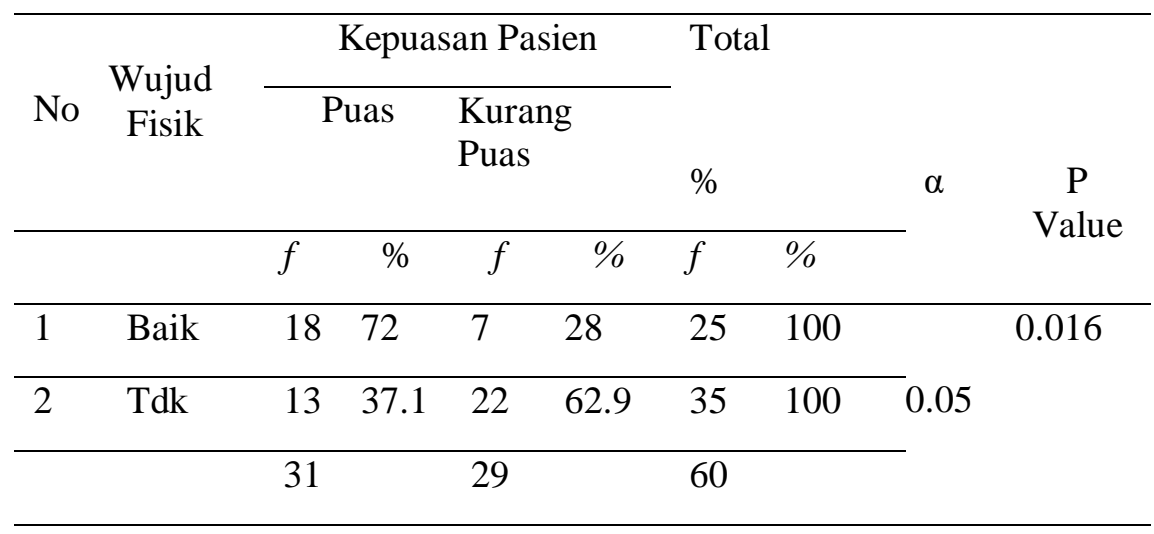

Tabel [2]. Distribusi Pengaruh Reliability Dengan Kepuasan Pasien

\begin{tabular}{|c|c|c|c|c|c|c|c|c|}
\hline \multirow{3}{*}{ No } & \multirow{3}{*}{ Reliability } & \multicolumn{4}{|c|}{ Kepuasan Pasien } & \multirow[b]{2}{*}{ Total } & \multirow{3}{*}{$\alpha$} & \multirow{3}{*}{$\begin{array}{c}\mathrm{P} \\
\text { Value }\end{array}$} \\
\hline & & \multicolumn{2}{|c|}{ Puas } & \multicolumn{2}{|c|}{ Kurang Puas } & & & \\
\hline & & $f$ & $\%$ & $f$ & $\%$ & $\%$ & & \\
\hline 1 & Baik & 23 & 71.9 & 9 & 28.1 & $32 \quad 100$ & & \\
\hline \multirow[t]{2}{*}{2} & Tidak & 8 & 28.6 & 20 & 71.4 & $28 \quad 100$ & 0.05 & 0.002 \\
\hline & & 31 & & 29 & & 60 & & \\
\hline
\end{tabular}

Tabel [3]. Distribusi Pengaruh Responsif Dengan Kepuasan Pasien

\begin{tabular}{|c|c|c|c|c|c|c|}
\hline \multirow[t]{3}{*}{$\overline{\text { No }}$} & \multirow{3}{*}{ Responsiveness } & \multicolumn{2}{|c|}{ Kepuasan Pasien } & \multirow{2}{*}{$\begin{array}{l}\text { Total } \\
\%\end{array}$} & \multirow[t]{2}{*}{$\alpha$} & \multirow{2}{*}{$\begin{array}{c}\mathrm{P} \\
\text { Value }\end{array}$} \\
\hline & & \multicolumn{2}{|c|}{ Puas Kurang Puas } & & & \\
\hline & & $f \quad \%$ & $\%$ & $f \quad \%$ & & \\
\hline 1 & Baik & $\begin{array}{ll}23 & 65 . \\
& 7\end{array}$ & 1234.3 & 35100 & \multirow{3}{*}{0.05} & \multirow{3}{*}{0.021} \\
\hline \multirow[t]{2}{*}{2} & Tidak & $8 \quad 32$ & $17 \quad 68$ & 25100 & & \\
\hline & & 31 & 29 & 60 & & \\
\hline
\end{tabular}


Tabel [4]. Distribusi Pengaruh Assurance Dengan Kepuasan Pasien

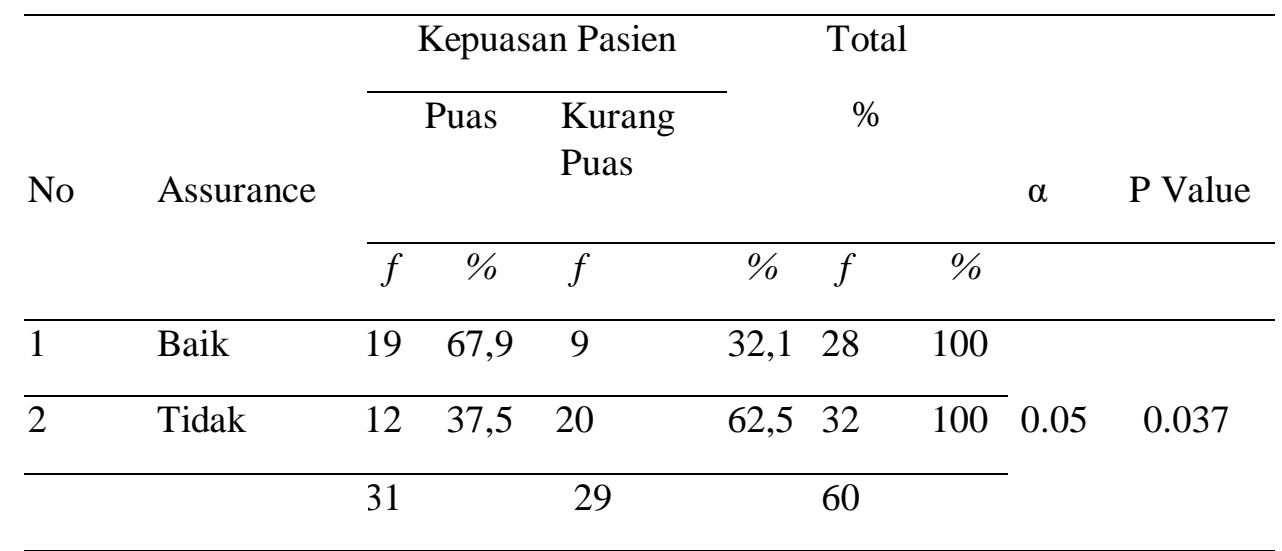

Tabel [5]. Distribusi Pengaruh Empati Dengan Kepuasan Pasien

\begin{tabular}{|c|c|c|c|c|c|c|c|c|c|}
\hline \multirow{3}{*}{ No } & \multirow{3}{*}{ Empathy } & \multicolumn{4}{|c|}{ Kepuasan Pasien } & \multicolumn{3}{|c|}{ Total } & \multirow{3}{*}{ P Value } \\
\hline & & & Puas & $\begin{array}{l}\text { Kur } \\
\text { Pua }\end{array}$ & & \multicolumn{2}{|l|}{$\%$} & \multirow[t]{2}{*}{$\alpha$} & \\
\hline & & $f$ & $\%$ & $f$ & $\%$ & $f$ & $\%$ & & \\
\hline 1 & Baik & 21 & 70 & 9 & 30 & 30 & 100 & \multirow{3}{*}{0.05} & \multirow{3}{*}{0.010} \\
\hline \multirow[t]{2}{*}{2} & Tidak & 10 & 33,3 & 20 & 66,7 & 30 & 100 & & \\
\hline & & 31 & & 29 & & 60 & & & \\
\hline
\end{tabular}

